\title{
Case Analysis of Damages to Control Hydraulics of the Leg in the Powered Roof Support Section
}

\author{
Janina Świątek ${ }^{1,{ }^{*}}$, and Kazimierz Stoiński ${ }^{1}$ \\ ${ }^{1}$ The Central Mining Institute, Poland
}

\begin{abstract}
The article discusses a case of security hazard in a longwall equipped with a properly selected chock shield support with two legs, technically efficient, introduced to the market and for operation in compliance with the requirements covering Polish hard coal mining. As a cause of the hazard an accidental coincidence was indicated, such as the occurrence of a tremor at an area with unfavourable geometry for the operation of the support section and leg (including the shift of the doubletelescopic leg from the 1st to the 2nd hydraulic stage) at the time of the mining process. Immediate safety measures were applied successfully. They were aimed at minimizing the conditions dangerous to the crew. The section was withdrawn and spragged again. As a result, the leg operated in full extension mode of the 1st hydraulic stage, obtaining the required strength and geometry of the section and leg. The presented case study will be additionally supplemented in the future with selected analytical and bench tests.
\end{abstract}

\section{Introduction}

The powered roof support was introduced to the market in compliance with the requirements resulting from the European Parliament Directives and the Polish standards correlated with them. The basic PN EN 1804 series standards that review mechanical requirements, exclude the case of their validity for operation in conditions of rock mass hazard. The Polish Minister of Energy Ordinance of November 23, 2016 is the supplement to Polish standards in the area regarding mining tremors (Dz. U. Nr 2017 poz. $1118 \S 523$ ust. 1, pkt. 1). It introduces the requirement for the sections to be yielded for the conditions of mining tremors hazard. Section yielding is its adaptation to additional dynamic loads as a derivative of mining tremors. One of the important protection means is to introduce pressure limits in the underpiston space of the leg, up to permissible level set on the basis of mechanical strength of the structure. The pressure limitation is implemented by the use of hydraulic valves. Due to operational requirements (expectations), the valves are placed as high as possible above the floor, which considerably extends the path of liquid stream, from under the piston to the valve. In such cases, there are unfavourable phenomena related to the occurrence of water hammers in the leg's control systems, significantly increasing with the increase in the diameter of the leg and the values of flows [13]. As a result of water hammers, damage occurs to the elements of the control hydraulics of the leg, including valves, pressure gauges, as well

\footnotetext{
${ }^{*}$ Corresponding author: jswiatek@gig.eu
} 
as STECKO connectors. Damage to the elements of the control hydraulics significantly decreases safety in the mining area. In some cases it may lead to automatic and unintentional slip of the section. The article presents discussed this type of event.

\section{Parameters of the analysed longwall}

The exploited longwall was $246 \mathrm{~m}$ long and $3.1 \mathrm{~m}$ high, and was adjacent to goafs from one side. The thickness of the seam in the analysed area ranged from 1.2 to $3.2 \mathrm{~m}$. The seam in the area of the longwall was located at an average depth of about 1010, it was inclined at an angle of up to $10^{\circ}$. The compressive strength of the coal of the seam and its surrounding rocks was about 32.0 MPa for the roof, about 14.0 MPa for the seam, and about 18.0 MPa for the floor. The longwall was equipped with a powered roof support, as presented in Fig. The basic technical parameters are listed in Table 1.

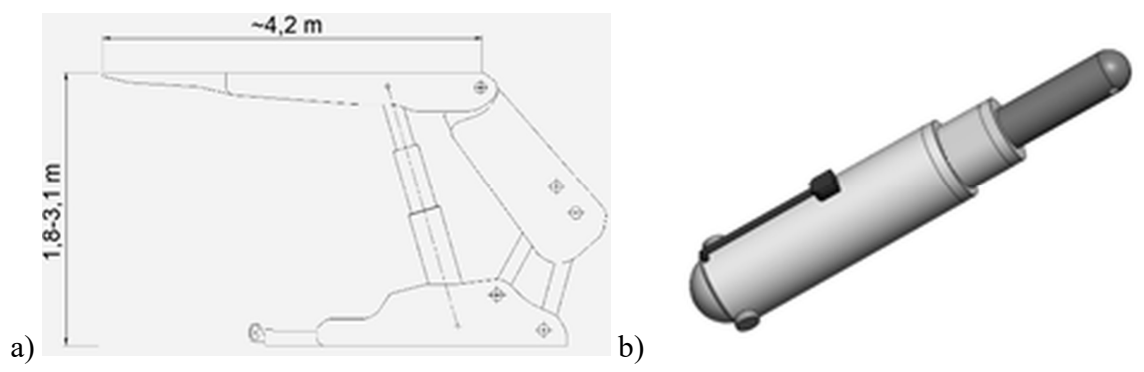

Fig. 1. The powered support section and leg applied in the case study.

Table 1. Basic technical parameters of the powered roof support.

\begin{tabular}{|l|l|}
\hline \multicolumn{2}{|c|}{ Powered chock shield supports with two legs } \\
\hline \multicolumn{2}{|c|}{ Geometric data } \\
\hline $\begin{array}{l}|c| \\
\text { - working height for seam where rock burst } \\
\text { occurs }\end{array}$ & $1.8-3.1 \mathrm{~m}$ \\
\hline - section division & $1.5 \mathrm{~m}$ \\
\hline - step of the section & $0.8 \mathrm{~m}$ \\
\hline \multicolumn{2}{|c|}{ Bearing data } \\
\hline - number of legs & 2 \\
\hline - leg's diameter & $\varnothing 0.3 / 0.23 \mathrm{~m}$ \\
\hline - leg's initial bearing capacity & $1.767 \mathrm{MN}$ \\
\hline - leg's working bearing capacity & $2.686 \mathrm{MN}$ \\
\hline - supply pressure & $25.0 \mathrm{MPa}$ \\
\hline - working pressure & $38.0 \mathrm{MPa}$ \\
\hline - leg's length, min/max & $1.365 / 2.91 \mathrm{~m}$ \\
\hline - $1^{\text {st/2nd }}$ level of a hydraulic jump & $0.765 / 0.78 \mathrm{~m}$ \\
\hline - control & remote local \\
\hline - leg's protection & spring-loaded valve \\
\hline - leg's overload coefficient & 2.0 \\
\hline
\end{tabular}

According to the method developed at GIG $[4,5]$, the support with the given parameters under the given geological and mining conditions ensured correct conditions for maintaining the roof (values of the load capacity index of the roof $g>0.8$ ). The roof load index was calculated taking into account the forecasted maximum energy of a tremor with the value of $2 \cdot 10^{6} \mathrm{~J}$ and included the load factor of the support $\mathrm{n}_{\mathrm{tz}}=1.22[1-3]$. 
According to the assessment of flows of the safety system of the leg $[9,11,12]$, the flow of the leg's safety system, $\mathrm{Q}=400 \mathrm{dm}^{3} \cdot \mathrm{min}^{-1}$, was assumed for calculations of the load of the powered roof support, at a pressure of 1.5 times the working load. Expected overloads for the above mentioned flows are shown in Fig. 2.

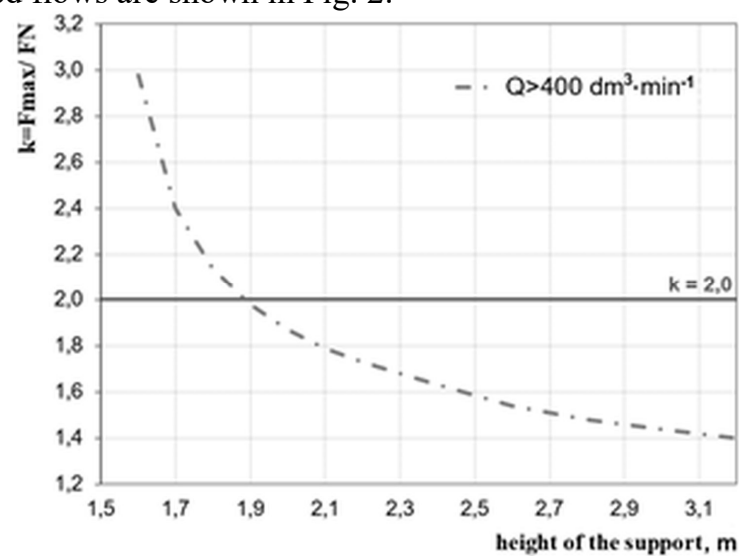

Fig. 2. Predicted overload of powered roof support's leg in the analysed case (for $n t z=1.22$ and application of hydraulic system with a flow of at least $\mathrm{Q}>400 \mathrm{dm} 3 \cdot \mathrm{min}-1)$.

The results indicate that the powered roof support should be yielded from a height of 1.9 $\mathrm{m}$, using a system with a minimum capacity of $400 \mathrm{dm}^{3} \cdot \mathrm{min}^{-1}$. This requires maintaining the liquid column under the first stage piston with a minimum height of $0.35 \mathrm{~m}$, with the correct section geometry.

\section{Description of effects}

The geological and mining conditions of operation changed. Due to the thinning of the exploited seam, the height of the exploited longwall decreased gradually, to approx. $2.0 \mathrm{~m}$, and the operating conditions deteriorated, which was manifested by roof falls in the face of the longwall area. In addition, at a guide height of $2.0 \mathrm{~m}$, a tremor of energy not exceeding $2 \cdot 10^{6} \mathrm{~J}\left(\mathrm{n}_{\mathrm{tz}}=1.22\right)$ occurred in the longwall, which caused dynamic load that impacted on the powered roof supports, which resulted in:

- damage to five pressure gauge systems (cutting off connection DN12 and damage to pressure gauges) - Photo 1, Fig. 3;

- damage to pressure limiting valves (loss of tightness, damaged seals) - Photo 2, Fig. 3;

- slip off two sections of the support due to damage to the pressure gauge systems (backrest of the canopies on the conveyor);

- roof rock fall.

The case described did not lead to any injury to the crew. 
a)

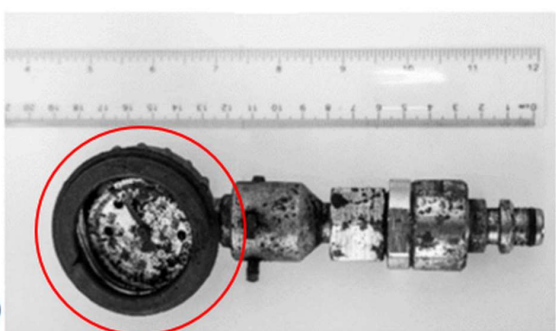

b)

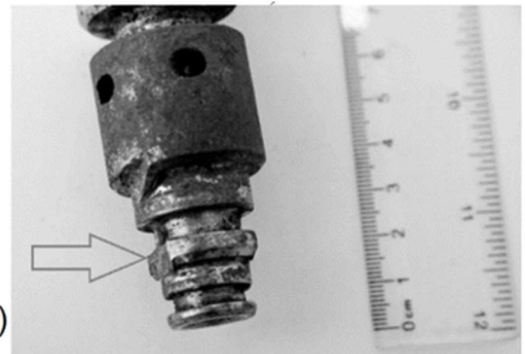

Photo. 1. Damaged manometers

c)

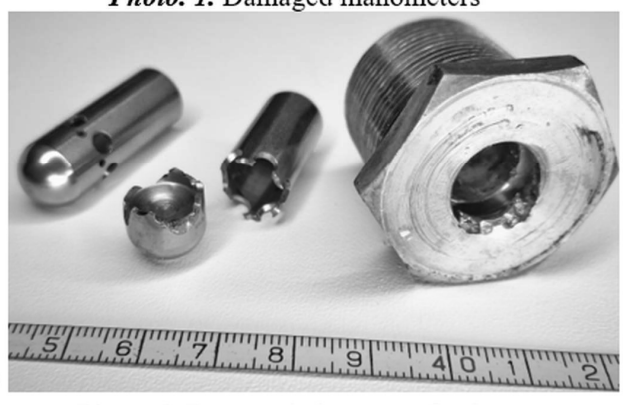

Photo. 2. Damaged elements of valves

Fig. 3. Damages of the equipment.

\section{Analysis of the causes of damage in the leg's control system}

For a properly operated double-telescopic leg with a bottom valve, its load capacity is calculated from dependence [8]:

- initial bearing capacity:

$$
\begin{gathered}
F_{w}=P_{w} \cdot S_{1} \\
F_{r}=P_{r} \cdot S_{1}
\end{gathered}
$$

where: $\mathrm{P}_{\mathrm{w}}$ - initial pressure, $\mathrm{P}_{\mathrm{r}}$ - working pressure, $\mathrm{S}_{1}$ - surface of the leg at $1^{\text {st }}$ stage position.

In the case of leg operating in the range of shifting from $1^{\text {st }}$ to $2^{\text {nd }}$ stage and clamping of the leg at $2^{\text {nd }}$ stage, the relations given above change. The load-bearing capacity of the leg changes (due to the smaller surface of the second stage of the leg), its rigidity changes rapidly, which often leads to vibrations in the control system, as well as difficulties in maintaining the roof. Fig. 4 schematically shows the cases described.

As presented in Fig. 4, during the shift of the leg from $1^{\text {st }}$ to $2^{\text {nd }}$ stage, the work of the leg is unstable, which can be described by the following formulas:

$$
\begin{gathered}
\mathrm{F}_{\mathrm{r}}=\mathrm{S}_{2} \cdot \mathrm{P}_{\mathrm{r}} \text { or } \mathrm{P}_{\mathrm{z}}(\text { depending on the impact of the rock mass) } \\
\mathrm{F}_{\mathrm{w}}=\mathrm{S}_{1} \cdot \mathrm{P}_{\mathrm{w}}
\end{gathered}
$$

where: $\mathrm{P}_{\mathrm{w}}$ - initial pressure, $\mathrm{P}_{\mathrm{r}}$ - working pressure, $\mathrm{S}_{2}-$ surface of the leg at $2^{\text {nd }}$ stage position.

After spragging the support due to the first and second stage rigidity, the bottom valve is opened (mechanical - displacement $1 \div 2 \cdot 10^{-2} \mathrm{~m}$ ) and the pressure is set to the working pressure $\left(\mathrm{P}_{\mathrm{r}}\right)$, which results in the leg's operating force to amount to:

$$
\mathrm{F}_{\mathrm{r}}=\mathrm{S}_{2} \cdot \mathrm{P}_{\mathrm{r}}
$$


For the analysed case, the initial load is respectively:

For leg at $1^{\text {st }}$ stage

$$
\mathrm{F}_{\mathrm{w}}=25 \cdot 10^{6}(\mathrm{~Pa}) \cdot 0.07065=1.767 \mathrm{MN}
$$

For leg at $2^{\text {nd }}$ stage

$$
\mathrm{F}_{\mathrm{w}}=25 \cdot 10^{6}(\mathrm{~Pa}) \cdot 0.04153=1.04 \mathrm{MN}
$$

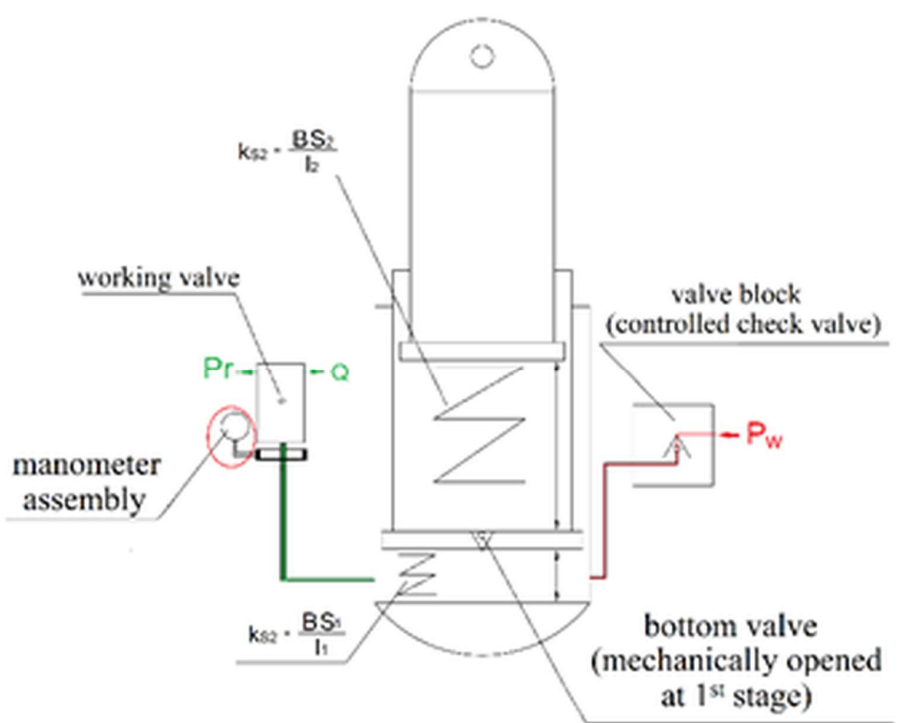

Fig. 4. Operation of the leg within the range of shifting from the $1^{\text {st }}$ to the $2^{\text {nd }}$ stage, where: $k_{s 1}-$ stiffness at the $1^{\text {st }}$ stage, $k_{\mathrm{s} 2}$ - stiffness at the $2^{\text {nd }}$ stage, $\mathrm{S}_{1}$ - surface of the $1^{\text {st }}$ stage, $\mathrm{S}_{2}$ - surface of the $2^{\text {nd }}$ stage, $1_{1}$ - length of the $1^{\text {st }}$ stage, $1_{2}$ - length of the $2^{\text {nd }}$ stage, $Q$ - capacity of the hydraulic system, $\mathrm{B}$ - compressibility of the hydraulic fluid.

The calculations presented indicate that the bearing capacity of the leg significantly decreased and corresponds to the load capacity of the leg with the diameter resulting from the second stage, which in the given case is $\varnothing 0.23 \mathrm{~m}$. The reduced working load was taken into account in further analysis regarding the condition for the support to be yielded.

A back analysis of the condition of the section's positive state was made using a valve with a capacity of $400 \mathrm{dm}^{3} \cdot \mathrm{min}^{-1}$, as shown in Fig. 5 .

As can be seen in Figure 5, in the case of proper support ( $1^{\text {st }}$ stage), it is compressed in the range from the height of $2.0 \mathrm{~m}$, while maintaining the liquid column under piston at the $1^{\text {st }}$ stage $\mathrm{PT} \geq 0.42 \mathrm{~m}$. During incorrect operation $\left(2^{\text {nd }}\right.$ stage) the support is yielded from the height of $2.35 \mathrm{~m}$, which results from the diameter of the $2^{\text {nd }}$ stage cylinder, while maintaining the height of the liquid column under the $2^{\text {nd }}$ stage PT $\geq 0.78 \mathrm{~m}$. It should be noted, however, that in this case the height of the liquid column under the first stage piston is practically nil, in which case the leg is not working properly.

In addition, as shown in Figure 4, an area where dangerous phenomena may occur is formed during the shift from $1^{\text {st }}$ to $2^{\text {nd }}$ stage, i.e. at the height of support of 2.3 to $2.6 \mathrm{~m}$. The research team estimates that the whole system excites within this range, which causes the occurrence of adverse phenomena in the form of impacts. 


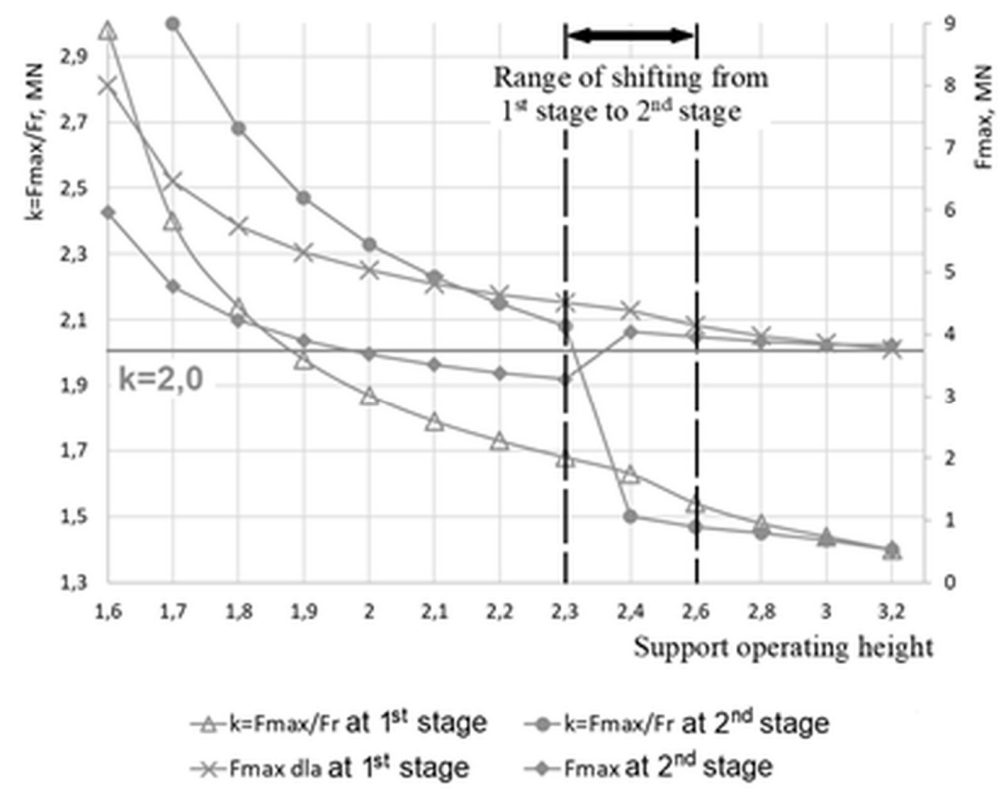

Fig. 5. Expected overload during operation of the hydraulic leg at $1^{\text {st }}$ stage and during operation at the time of shift from $1^{\text {st }}$ to $2^{\text {nd }}$ stage.

The operation of the support at the $2^{\text {nd }}$ stage also significantly affects the roof maintenance conditions, as shown in Fig. 6, using the load capacity index of the ceiling $g$ according to the method developed at GIG $[4,5]$.

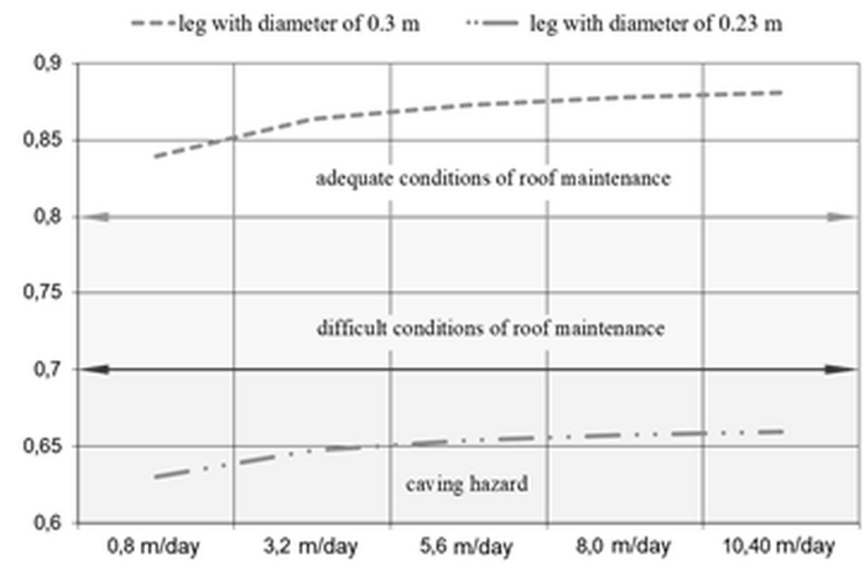

Fig. 6. Index of load-bearing capacity of the $g$ roof during the operation of the leg at the $1^{\text {st }}$ and $2^{\text {nd }}$ stage.

The calculations indicate that when the operating parameters of the leg are correct, the bearing capacity of the roof support will be sufficient to protect the excavation against the dynamic impact of the rock mass, which largely depends on the diameter of the leg $\varnothing 0.30 \mathrm{~m}$ - the $g$ factor $\geq 0.84$. In the case when the load-bearing capacity of the operating support resulting from the diameter of the $2^{\text {nd }}$ stage, the $g$ indicator significantly decreases $-g \geq 0.63$, and in accordance with the method developed at GIG, there is a risk of caving. This was confirmed in practice. The drop in the value of the $g$ indicator in this case results mainly from the size of the $2^{\text {nd }}$ stage cylinder's diameter, $\varnothing 0.23 \mathrm{~m}$ (too low bearing capacity of the support). 
In addition, the reason for the difficulties when maintaining the longwall could be the failure to maintain the correct geometry of the support section (lack of parallelism between the canopy and the floor base - excessive lifting of the canopy). Supporting the roof with the entire surface of the canopy is extremely important, since the linear support (e.g. the end of the canopy) can lead to destruction of the structure of the roof rocks, and thus to impediments in the proper maintenance of the longwall.

The change of support parameters as a result of maintaining poor work geometry is shown in Table $2[6,7]$.

Table 2. Dependences of the canopy inclination angle in relation to the length and angle of the leg inclination.

\begin{tabular}{|c|c|c|c|}
\hline $\begin{array}{c}\text { Canopy inclination } \\
\text { angle to the floor } \\
\text { base }\left[{ }^{\circ}\right]\end{array}$ & $\begin{array}{c}\text { The length of the leg } \\
\text { in relation to the } \\
\text { angle of inclination } \\
\text { of the canopy [mm] }\end{array}$ & $\begin{array}{c}\text { Leg inclination } \\
\text { angle }\left[{ }^{\circ}\right]\end{array}$ & $\begin{array}{c}\text { Distance between the } \\
\text { end of the canopy and } \\
\text { the floor [m] }\end{array}$ \\
\hline 0 & 1.787 & 23.38 & $2.000^{*)}$ \\
\hline 5 & 1.862 & 22.28 & 2.364 \\
\hline 10 & 1.935 & 21.10 & 2.724 \\
\hline 15 & 2.005 & 19.80 & 3.077 \\
\hline \multicolumn{2}{|c}{} \\
\hline
\end{tabular}

\section{Conclusion}

This article analyses the operating conditions of a powered roof support (with a doubletelescopic leg, $0.3 \mathrm{~m}$ diameter) adequately selected in terms of load-bearing capacity for the mining and geological conditions of the longwall. Despite the fact that the support was adequately selected in terms of resistance, it did not provide adequate work safety, due to its maintenance height.

As a result of the thinning of the deck, the height of the support operating area was successively lowered, which led to its operation on the $2^{\text {nd }}$ stage of extension of the leg, without maintaining the appropriate column of liquid under the piston at $1^{\text {st }}$ stage position. The tests results indicate that in this case the support does not have adequate bearing capacity and operates in the hazardous area in which the entire system is excited and, consequently, adverse effects occur in the form of water hammers in the control system.

Immediate safety measures were applied successfully. They were aimed at minimizing the conditions dangerous to the crew. The section was withdrawn and spragged again. As a result, the leg operated in full extension mode of the $1^{\text {st }}$ hydraulic stage, obtaining the required strength and geometry of the section and the leg.

Difficulties described in the article are significant in terms of safety of the crew and the continuity of the production process, therefore, research which include bench tests of the leg to characterize its work and a numerical analysis of flows in the leg's valve block will further describe the phenomenon.

\section{References}

1. A. Biliński, Zeszyty Naukowe AGH, 2, 85 (1985)

2. A. Biliński, Ocena stanu zagrożenia tapnięciem wyrobiska eksploatacyjnego (Komunikat GIG, Katowice, 1992)

3. A. Biliński, Zasady utrzymania wyrobiska w ścianach zawałowych (Prace GIG, Katowice, 1992) 
4. A. Biliński, Metoda doboru obudowy ścianowych wyrobisk wybierkowych $i$ chodnikowych do warunków pola eksploatacyjnego (CMG Komag, Gliwice, 2005)

5. A. Biliński, T. Kostyk, S. Prusek, Bezpieczeństwo i Ochrona Pracy w Górnictwie, 3, 50 (1997)

6. M. Płonka, S. Rajwa, Wiadomości Górnicze, 10, 611-616 (2009)

7. M. Płonka, S. Rajwa, Mining - Informatics, Automation and Electrical Engineering, 4, 45-64 (2018)

8. S. Rajwa, Wptyw konstrukcji stojaka hydraulicznego $w$ ścianowej obudowie zmechanizowanej na utrzymanie stropu: Rozprawa doktorska (GIG, Katowice, 2004)

9. S. Rajwa, Zasady bezpiecznego stosowania obudów zmechanizowanych $w$ warunkach występowania wstrząsów górotworu (GIG, Katowice, 2007)

10. Rozporzadzenie Ministra Energii z dnia 23 listopada 2016 r. Dz. U. Nr 2017 poz. 1118 $\S 523$ ust. 1, pkt. 1

11. K. Stoiński, Obudowy górnicze w warunkach zagrożenia wstrzasami górotworu (GIG, Katowice, 2000)

12. K. Stoiński, Metoda upodatnienia sekcji zmechanizowanych obudów ścianowych (GIG, Katowice, 2006)

13. D. Szurgacz, Journal of Sustainable Mining, 14:4. (2015) DOI: http://dx.doi.org/10.1016/j.jsm.2015.12.001 